\title{
スギ抽出物による熱ショックタンパク発現誘導の抑制効果
}

\author{
宮越順二, ${ }^{*}, a$ 松原恵理, ${ }^{b}$ 成田英二郎, ${ }^{a}$ \\ 小山 眞, ${ }^{a}$ 清水陽子, ${ }^{a}$ 川井秀一 $c$
}

\section{Suppressive Effects of Extract of Cedar Wood on Heat-induced Expression of Cellular Heat Shock Protein}

\begin{abstract}
Junji Miyakoshi, ${ }^{*, a}$ Eri Matsubara,${ }^{b}$ Eijiro Narita, ${ }^{a}$ Shin Koyama, ${ }^{a}$ Yoko Shimizu, ${ }^{a}$ and Shuichi Kawaic ${ }^{a}$ Division of Creative Research and Development of Humanosphere, Research Institute for Sustainable Humanosphere, Kyoto University; Gokasho, Uji, Kyoto 611-0011, Japan: ${ }^{b}$ Department of Wood-Based Materials, Forestry and Forest Products Research Institute; Matsunosato 1, Tsukuba, Ibaraki 305-8687, Japan: and ${ }^{\circ}$ Graduate School of Advanced Integrated Studies in Human Survivability, Kyoto University; Higashi-Ichijyokan IF, Naka-adachi-cho 1, Yoshida, Sakyo-ku, Kyoto 606-8306, Japan.
\end{abstract}

(Received July 6, 2017; Accepted August 30, 2017; Advance publication released online September 20, 2017)

In recent years, highly antimicrobial properties of cedar heartwood essential oil against the wood-rotting fungi and pathogenic fungi have been reported in several papers. Antimicrobial properties against oral bacteria by hinokitiol contained in Thujopsis have been also extensively studied. The relation of naturally derived components and human immune system has been studied in some previous papers. In the present study, we focused on Japanese cedar, which has the widest artificial afforestation site in the country among various tree species. Extract oil was obtained from mixture of sapwood and heartwood of about 40-year cedar grown in Oguni, Kumamoto, Japan. We examined the influence of extract components from Japanese cedar woods on the expression of heat shock protein 70 (Hsp70) during heating, and on the micronucleus formation induced by the treatment of bleomycin as a DNA damaging agent. Cell lines used in this study were human fetal glial cells (SVGp12) and human glioma cells (MO54). Remarkable suppression of the Hsp70 expression induced by heating at $43^{\circ} \mathrm{C}$ was detected by the treatment of cedar extract in both SVGp12 and MO54 cells. We also found that cedar extract had an inhibitory tendency to reduce the micronucleus formation induced by bleomycin. From these results, the extract components from Japanese cedar woods would have an inhibitory effect of the stress response as a suppression of the heat-induced Hsp70 expression, and might have a reductive effect on carcinogenicity.

Key words_ _ cedar wood extract; human cell; heat shock protein; micronucleus formation

\section{緒 言}

木材の化学成分を大きく分けると，リグニンやへ ミセルロース，セルロースといつた骨格を担う主要 な 3 成分と, 多様で樹種を化学的に特徵づける抽出 成分がある．抽出成分に含まれる化合物として色や 二オイなど木材の特徴に係わる物質から，抗菌性や 殺ダ二牲など生物活性を有する物質まで数多く報告 されている．近年は例えば，スギ心材精油の木材腐 朽菌や病原性菌に対する高い抗菌性1)や，ヒバ材に 多く含まれるヒノキチオールによる口腔内細菌に対

$a$ 京都大学生存圈研究所生存圈開発創成研究系, $b$ 森林 研究・整備機構森林総合研究所, $c$ 京都大学大学院総合 生存学館（思修館）

*e-mail: miyakoshi@rish.kyoto-u.ac.jp
する抗菌性が報告されている. ${ }^{2)}$ また, ヒノキ枝心 材部へキサン抽出物や $\alpha$-カジノールなどのセスキ テルペン類による抗蟻性, ${ }^{3)}$ ヒノキ葉枝精油に対す るハエの忌避性4)も示唆されている.

一方, 細胞は種々のストレスにより, 細胞内で熱 ショックタンパク質 (heat shock protein; Hsp) の 合成を誘導することが知られている. ${ }^{5-8)}$ また, Hsp は種々のがん組織で発現が促進されたり，がんの悪 性度や予後との関連性が明らかにされつつあ る. ${ }^{9-11)} \mathrm{Hsp}$ は分子シャペロンとしての役割を担つ ていることが知られており，この分子シャペロンの 発現抑制により，アポトーシスを誘導して，腫瘍の 増殖を阻害することが報告されている. ${ }^{12,13)}$

Hsp と植物の関係に目を移すと, 天然物からの 抽出物やそれらに含まれる化合物と Hsp に関する 
既往研究が散見される。渡邊ら ${ }^{14)}$ は，生薬が Hsp70 の発現に及ぼす影響を検証し，印度蛇木 （Rauwolfia serpentina）などに，発現増加活性がみ られたと報告している。フフラホノイドの一種で, ソ バやタマネギなどに多く含まれるケルセチンは Hsp70 の発現誘導を抑制する物質としてよく知ら れている. ${ }^{15)}$ また， ウコンなどに含まれ，ポリフェ ノールの一種であるクルクミンも濃度依存的に細胞 死を誘導する. ${ }^{16)}$ ほかにも，トリテルペノイドの一 種であるセラストロールの神経細胞保護作用, 17) レ モン精油や主要成分であるリモネンの胃保護作用 ${ }^{18)}$ など，Hsp の関与を示唆する研究が報告されてい る.

しかし，これまで木材の抽出成分が Hsp に与え る影響について検証した研究はほとんど見当たらな い. そこで本研究では，様々な樹種のなかでも国内 で最も広く植林されているスギに注目した。 ヒト脳 由来細胞を用いて，温熱ストレスを与えたり， DNA 損傷誘発物質を処理し，スギ抽出物が，これ らの処理に対して，ストレスタンパクとしての Hsp70 の発現，並びに発がん性に関与する細胞遺 伝毒性指標の 1 つである小核形成に与える影響を検 討した.

\section{材 料と方 法}

\section{1. 精油採取及び試料調整 低温乾燥させた熊} 本県産の約 40 年生スギ (Cryptomeria japonica) 材を入手し，チッパーとウィレーミルを用いて小片 化し，水蒸気蒸留装置を用いて精油を抽出した。得 られた精油は実験まで遮光して冷蔵庫で保管した。 精油はジメチルスルホキシド [dimethyl sulfoxide; DMSO, (株)和光純薬工業, 大阪］で用時調製し, 供試試料とした。

水蒸気蒸留にて得られた精油を, GC-MS（ガス クロマトグラフ質量分析計）分析に供した。 GCMS 装置は GCMS-QP2010［(株)島津製作所，京都］ を用い, Rtx-5ms カラム [(株) ジーエルサイエンス 社，東京，膜厚 $1.0 \mu \mathrm{m} \times$ 内径 $0.25 \mu \mathrm{m} \times$ 長さ $30 \mathrm{~m}$ ] を装着して分析した。分析条件は以下の通りであ る：気化室 $250^{\circ} \mathrm{C}$, インターフェイス $250^{\circ} \mathrm{C}$, 昇温 プログラム $\left(50^{\circ} \mathrm{C}\right.$ で 3 分保持, $50^{\circ} \mathrm{C}$ から $170^{\circ} \mathrm{C}$ ま で毎分 $30^{\circ} \mathrm{C}, 170^{\circ} \mathrm{C}$ から $250^{\circ} \mathrm{C}$ まで毎分 $4^{\circ} \mathrm{C}$ で昇温, $250^{\circ} \mathrm{C}$ で 10 分保持)。各成分の同定には NIST14 ラ
イブラリを用いた.

2. 細胞と細胞生存率 ヒト脳由来の胎児グリ ア細胞 $(\mathrm{SVGp} 12)^{19,20)}$ 及び脳腫瘍（神経膠腫）由来 細胞（MO54） ${ }^{21,22)}$ を用いて，スギ抽出物による細 胞生存率への影響を評価した。細胞は L-グルタミ ン［(株)和光純薬工業］を含有する Eagle MEM 培 地 [(株) 和光純薬工業］に $10 \%$ のウシ胎仔血清 (fetal bovine serum; FBS, Biowest, Nuaillé) を添加 した培地で培養した。 SVGp12 細胞の培地にはさら にピルビン酸ナトリウム溶液 [(株)和光純薬工業 $]$ を $1 \%$ と MEM 非必須アミノ酸溶液 [Sigma-Aldrich Co. LLC., St. Louis] を1\%添加した. 保存したス ギ抽出物を希釈し, 細胞培養中に最大濃度 $10 \mu \mathrm{L} /$ $\mathrm{mL}(1 \%)$ を入れて 1 時間培養し，リン酸緩衝生 理食塩水 (phosphate buffered saline; PBS, Takara Bio Inc., 草津) で洗浄後，2 日培養した。 また, $43^{\circ} \mathrm{C}$ で 2 時間処理した細胞と，最終濃度 $10 \mu \mathrm{L} / \mathrm{mL}$ （1％）の DMSO を添加して 1 時間培養した細胞を コントロールとした。細胞生存率評価は WST 試験 (Premix WST-1 Cell Proliferation Assay System, Takara Bio Inc.) を用いた。

3. 熱ショックタンパク質の発現＼cjkstart熱ショック タンパク質は，細胞が熱などによる処理を受けた場 合に発現する，熱ショックとして，細胞を $43^{\circ} \mathrm{C}$ 中 で 2 時間培養した。一方，熱ショック処理 1 時間経 過後にスギ抽出物を添加し，さらに 1 時間温熱処理 を行った． 熱処理の後，細胞をPBS で洗浄し，細 胞溶解液 (CelLytic solution, Sigma-Aldrich Co. LLC.) で回収した。溶解物はサンプルバッファー と混合し， $100^{\circ} \mathrm{C}$ で 1 分間煮沸した。次に溶解物を 水上で冷却した。 タンパク質 $(5 \mu \mathrm{g} / \mathrm{well})$ は SDSポリアクリルアミドゲル電気泳動［SDS-PAGE：20 $\mathrm{mA}, 35 \mathrm{~V}$ ，（株)和光純薬工業]で分離した．電気 泳動後, iBlot（Life Technologies，Carlsbad）を用 いてタンパク質をゲルからニトロセルロースメンブ レンに転写した。メンブレンの非特異結合部はウシ 血清アルブミン (bovine serum albumin; BSA, Life Technologies）ブロッキング剤でブロック処理し た。この試験では一次抗体に anti-Hsp70 マウスモ ノクローナル抗体 (Stress Marq Biosciences Inc., Victoria, $1: 200)$ と, anti- $\beta$-actin マウスモノクロー ナル抗体（Sigma-Aldrich Co. LLC., $1:$ 1000）を用 いた。 二次抗体として, anti マウスモノクローナル 
抗体 (GE Healthcare, 東京, $1:$ 1000) を用いた. 免疫染色後，メンブレンをペルオキシダーゼ (horseradish peroxidase; HRP, GE Healthcare) で 標識し, 最後に ATTO Image Analysis Software [(株)アトー，東京］を用いてバンドを検出し，分 析した. ${ }^{23)}$

4. 小核形成試験 細胞実験で遺伝毒性の評価 指標の 1 つである，小核形成頻度へのスギ抽出物の 影響評価を行った。スギ抽出物は濃度依存性の有無 も検討するため， $0.05 \%, 0.02 \%$ ，及び $0.002 \%$ で 行つた. DNA 損傷誘発剤として, 培養中の細胞に最 終濃度 $10 \mu \mathrm{g} / \mathrm{mL}$ のブレオマイシン (Sigma-Aldrich

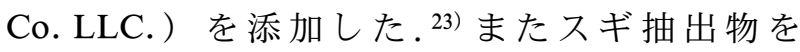
$\mathrm{SVGp} 12$ 細胞へ $0.2 \mu \mathrm{L} / \mathrm{mL} ， 0.02 \mu \mathrm{L} / \mathrm{mL} \quad(0.02 \%$, $0.002 \%), \quad$ MO54 細胞へ $0.5 \mu \mathrm{L} / \mathrm{mL}, 0.2 \mu \mathrm{L} / \mathrm{mL}$ $(0.05 \%, 0.02 \%)$ 添加して 1 時間培養した。 細胞を PBS で 3 回洗浄した後, サイトカラシン B (SigmaAldrich Co. LLC.) を最終濃度 $3 \mu \mathrm{g} / \mathrm{mL}$ 添加して 24 時間培養した。次に $70 \%$ の冷エタノール中に細 胞を回収し， $-20^{\circ} \mathrm{C}$ で 30 分間固定した。さらに PBS で穏やかに洗浄した後, 核酸染色色素 (propidium iodide; PI, Invitrogen, Carlsbad) で染 色した。最後に細胞をサイトスピン（Shandon Southern Ltd., Runcorn) でガラススライドに展開 した. ${ }^{23)}$ Countryman \& Heddle ${ }^{24)}$ による基準に従っ て, 各実験で， 300 個の二核細胞にある小核形成頻 度を集計した。

5. 統計処理 データは, ダネットの多重比較 検定並びにテューキーの検定を用いて統計比較を 行った。各実験（生存率，Hsp の発現，及び小核 形成）は独立して少なくとも 3 回繰り返し, デー夕 は平均值士標準偏差で示した。

結 果

1. スギ抽出物に含まれる化学成分組成 水蒸 気蒸留法により採取した精油には，通常，モノテル ペン類 $\left(\mathrm{C}_{10}\right)$, セスキテルペン類 $\left(\mathrm{C}_{15}\right)$, ジテルペ ン類 $\left(\mathrm{C}_{20}\right)$ が含まれる. GC-MS を用いたスギ材精 油中に含まれる化合物の分析結果を Table 1 に示す.

Table 1 より，セスキテルペン炭化水素類が 82.2 \%，含酸素セスキテルペン類が $15.1 \%$ であり，セ スキテルペン類が全体の $97 \%$ 以上が含まれること が分かった。モノテルペン類は含まれず，ジテルペ
Table 1. Chemical Composition of Cedar Wood Essential Oil

\begin{tabular}{ccc}
\hline \hline No. & Compounds & Composition $(\%)$ \\
\hline 1 & $\alpha$-Cubebene & 1.71 \\
2 & $\alpha$-Copaene & 0.73 \\
3 & $\beta$-Cubebene & 1.11 \\
4 & Caryophyllene & 1.43 \\
5 & Muurola-3,5-diene & 1.63 \\
6 & Humulene & 1.40 \\
7 & Cadina-1 (6) ,4-diene & 7.25 \\
8 & $\alpha$-Muurolene & 9.17 \\
9 & $\gamma$-Muurolene & 3.01 \\
10 & Muurola-4(15),5-diene & 4.88 \\
11 & $\delta$-Cadinene & 34.77 \\
12 & $\gamma$-Cadinene & 3.18 \\
13 & Epizonarene & 9.87 \\
14 & Cadina-1,4-diene & 2.09 \\
15 & Elemol & 0.74 \\
16 & Greenol & 1.12 \\
17 & di-epi-1,10-Cubenol & 6.04 \\
18 & epi-Cubenol & 5.70 \\
19 & T-Cadinol & 0.23 \\
20 & $\alpha$-Eudesmol & 1.04 \\
21 & Cryptomerione & 0.18 \\
22 & Abietadiene & 2.76 \\
\hline
\end{tabular}

ン類は Abietadiene のみであった。また $\delta$-Cadinene は全成分中の約 35\%の含有量を占め, $\alpha$-Muurolene や Cadina-1 (6) ,4-diene, di-epi-1,10-Cubenol などの 含有量も比較的多かった (Table 1).

2. 細胞生存率 スギ抽出物による細胞毒性に より，細胞死や細胞周期停止などの細胞増殖を阻害 するような作用があるなら，細胞生存率に影響を及 ぼすと考えられる．SVGp12 細胞とMO54 細胞を 用いた WST 試験を行った結果を Fig. 1 と 2 に示 す。スギ抽出物を $0.05 \%$ 以下で 1 時間処理をした 細胞生存率は, SVGp12 細胞と MO54 細胞とも に，無処理コントロールや DMSO 単独処理との間 で有意差がみられなかつた。つまり，スギ抽出物濃 度の $0.05 \%$ 以下で 1 時間処理では，両細胞株とも 細胞死には至っていない。一方，スギ抽出物濃度 $0.1 \%$ 以上では，無処理コントロールやDMSO 単独 処理と比べて細胞生存率に有意な減少がみられ，両 細胞ともに $0.1 \%$ で約 $50 \%$ 生存率， $0.2 \%$ で, SVGp12 細胞では約 $20 \%$ 生存率, MO54 細胞では 約 $40 \%$ 生存率であった。

3. 熱ショックタンパク質 Hsp70 の発現 $43^{\circ} \mathrm{C}$ の熱処理 2 時間，スギ抽出物単独処理 1 時間， $43^{\circ} \mathrm{C}$ 


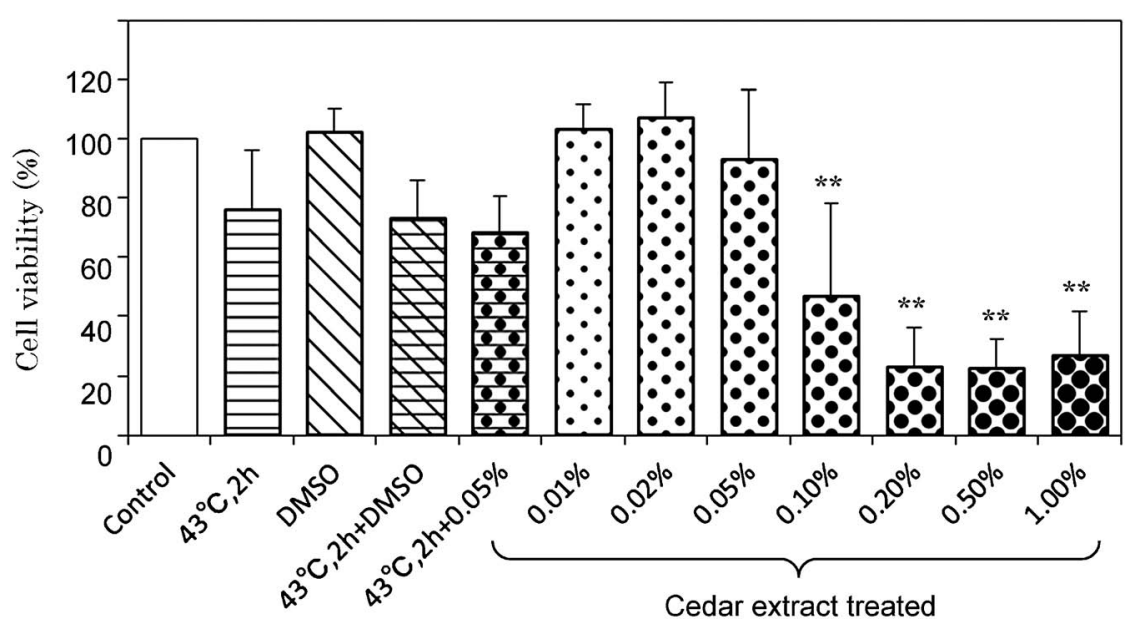

Fig. 1. Cell Survival in SVGp12 Cells

After the treatment of $43^{\circ} \mathrm{C}$ heating, DMSO alone, or extract components from Japanese cedar woods with various concentrations, cell survival was measured using WST assay. Results obtained from at least three independent runs are presented as mean \pm S.D. ${ }^{* *} p<0.01$.

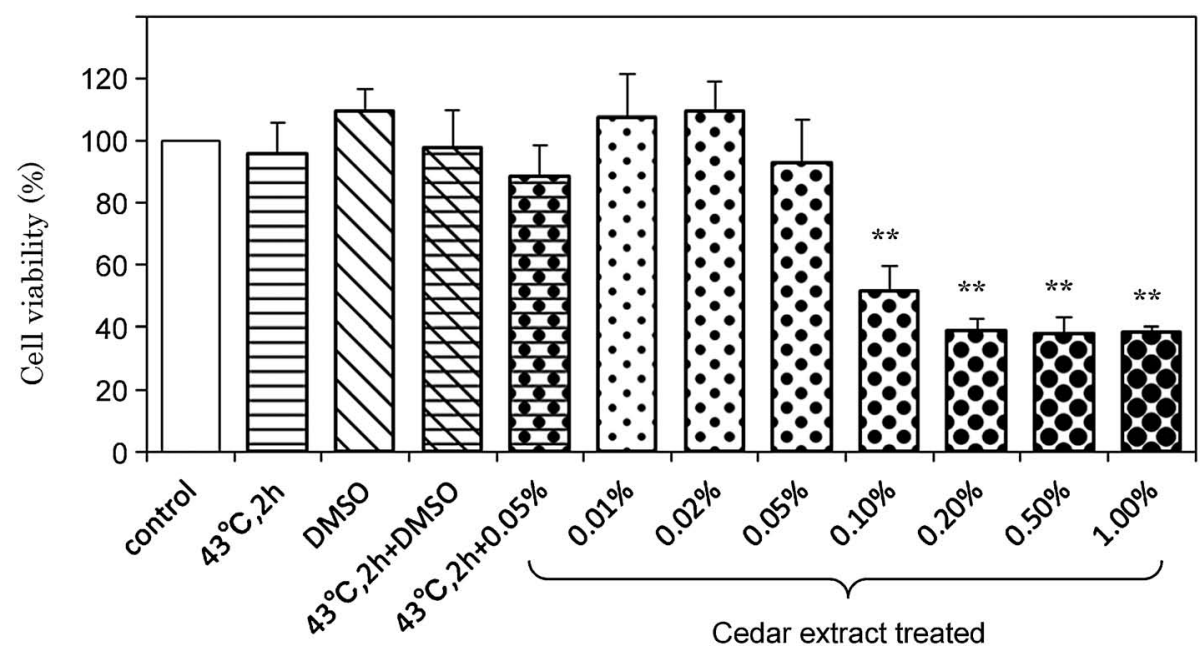

Fig. 2. Cell Survival in MO54 Cells

After the treatment of $43^{\circ} \mathrm{C}$ heating, DMSO alone, or extract components from Japanese cedar woods with various concentrations, cell survival was measured using WST assay. Results obtained from at least three independent runs are presented as mean \pm S.D. ${ }^{* *} p<0.01$.

温熱とスギ抽出物併用処理（熱処理 1 時間十スギ抽 出物と同時に熱処理 1 時間), さらに溶解剂対照と して最終濃度 $10 \mu \mathrm{L} / \mathrm{mL}(1 \%)$ のMSO 単独処理 1 時間と $43^{\circ} \mathrm{C}$ 温熱 $+\mathrm{DMSO}$ 処理後の細胞における Hsp70 の発現を Fig. 3 と 4 に示す。なお，スギ抽 出物の濃度は, 細胞生存率に影響を及ぼさない濃度 (Figs. 1 and 2) で最も高い $0.05 \%$ 用いた. Hsp70 の発現比較評価は, $\beta$ アクチン発現量で標準化した.

SVGp12 細胞及び MO54 細胞ともに, $43^{\circ} \mathrm{C}$ 熱処理 をした場合に Hsp70 発現量が有意に増加した。一 方, 熱処理とスギ抽出物の併用処理によって, Hsp70 発現量は著しく抑制された. スギ抽出物単 独処理 1 時間並びに DMSO 単独処理 1 時間では,
Hsp70 発現量は無処理対照と有意な差はなかっ た.さらに, $43^{\circ} \mathrm{C}$ 温熱 $+\mathrm{DMSO}$ 処理によっては, 温熱単独とほぼ同レベルの Hsp70 発現量が確認さ れた。

4. 小核形成 $43{ }^{\circ} \mathrm{C}$ 温熱処理で誘発された Hsp70の発現が，スギ抽出物の同時処理により著 しく抑制された（Figs. 3 and 4)。一方，これまでに Hsp は種々のがん組織で発現が促進されたり，が んの悪性度や予後との関連性が明らかにされつつあ

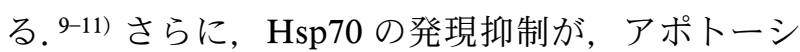

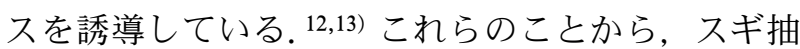
出物が発がんに関して修飾効果を持っているかどう かの可能性について検索した。具体的には，細胞に 


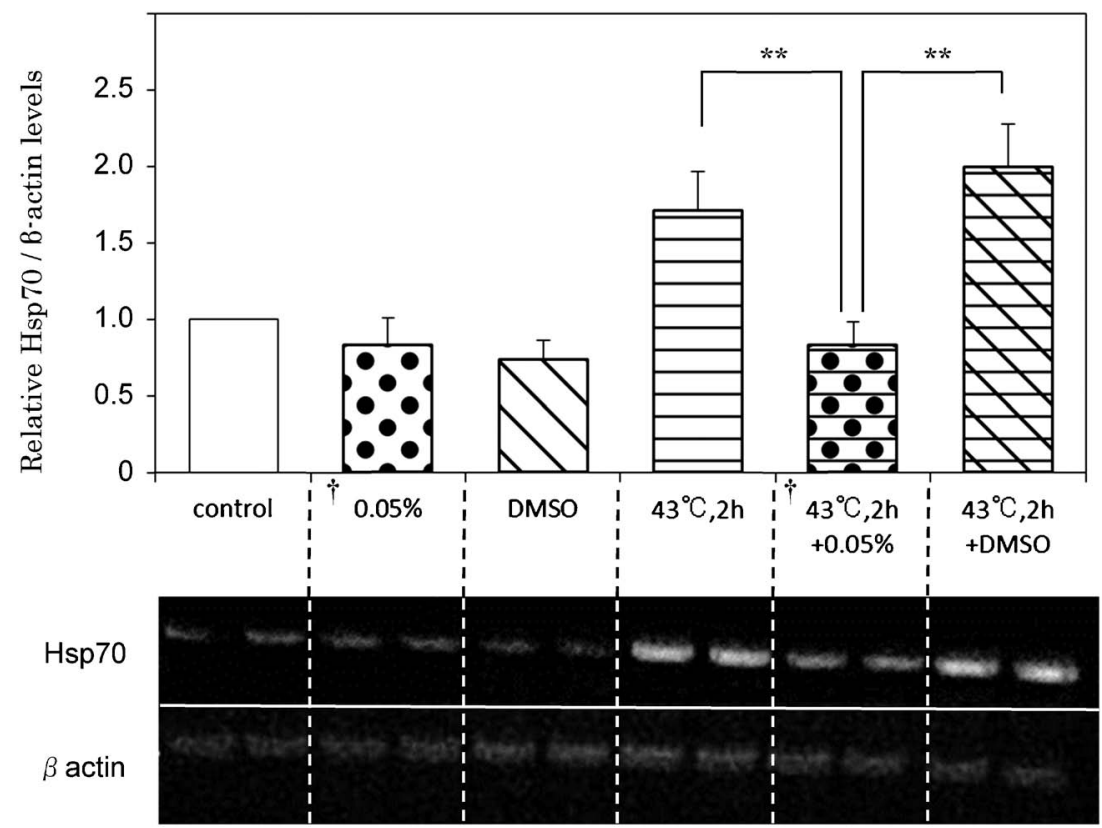

Fig. 3. Hsp70 Expression by the Treatment with $43^{\circ} \mathrm{C}$ Heating and/or Extract Components from Japanese Cedar Woods in SVGp12 Cells

After the treatment of $43^{\circ} \mathrm{C}$ heating, DMSO alone, or extract components from Japanese cedar woods, or $43^{\circ} \mathrm{C}$ heating with the extract, cellular proteins were extracted. Hsp70 expression was measured by Western blotting using anti-Hsp70 monoclonal antibody and anti- $\beta$-actin monoclonal antibody. Each sample was applied in two lanes. Results obtained from at least three independent runs are presented as mean \pm S.D. ${ }^{\dagger}$ Treatment with extract components from cedar wood, ${ }^{* *} p<$ 0.01 .

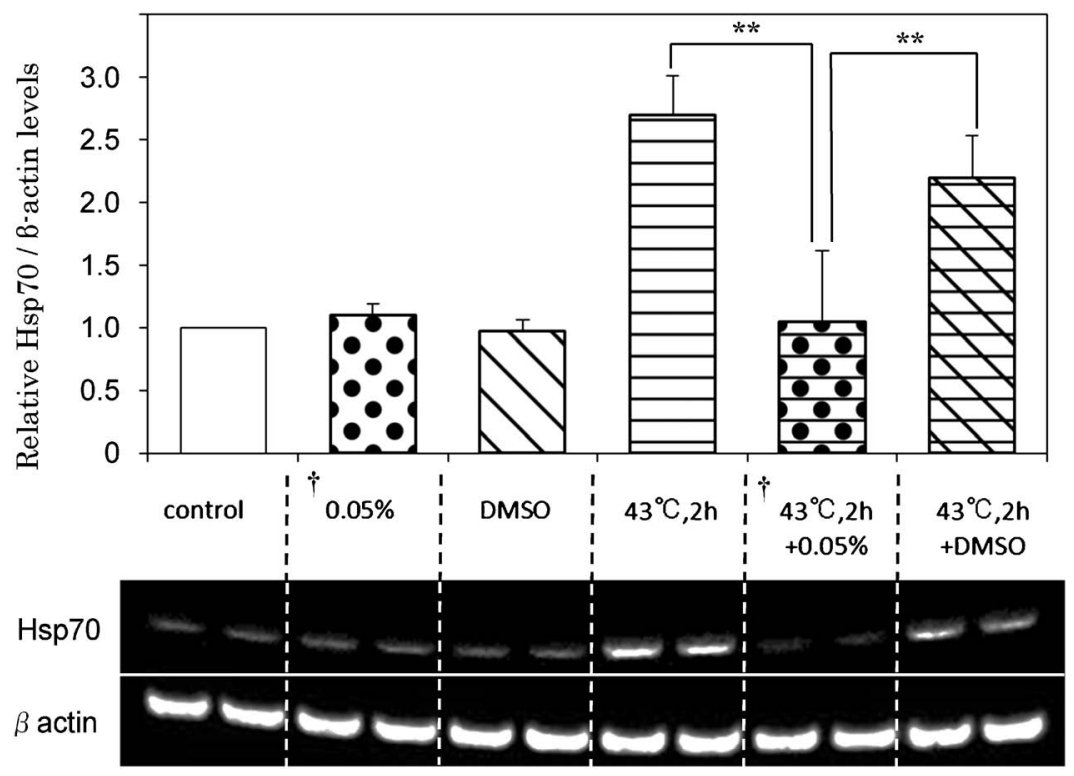

Fig. 4. Hsp70 Expression by the Treatment with $43^{\circ} \mathrm{C}$ Heating and/or Extract Components from Japanese Cedar Woods in MO54 Cells

After the treatment of $43^{\circ} \mathrm{C}$ heating, DMSO alone, or extract components from Japanese cedar woods, or $43^{\circ} \mathrm{C}$ heating with the extract, cellular proteins were extracted. Hsp70 expression was measured by Western blotting using anti-Hsp70 monoclonal antibody and anti- $\beta$-actin monoclonal antibody. Each sample was applied in two lanes. Results obtained from at least three independent runs are presented as mean \pm S.D. ${ }^{\dagger}$ Treatment with extract components from cedar wood, ${ }^{* *} p<$ 0.01 . 

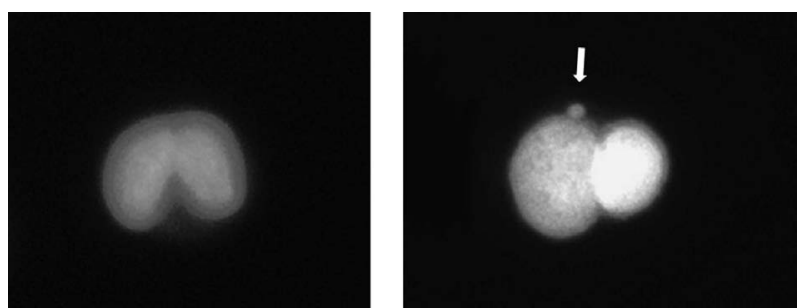

Fig. 5. Micronucleus Formation in SVGp12 Cells

left: Binucleated cell without bleomycin treatment, control, right: Binucleated cell treated by bleomycin. Cells were fixed and stained with propidium iodide (PI). Micronucleus is shown by arrow (right).

おける発がん性評価指標の 1 つである小核形成につ いて，スギ抽出物の影響の有無を調べた.

小核形成試験は染色体異常を評価する方法の 1 つ である．細胞分裂の際に核に取り込まれなかった無 動原体染色体断片や染色体そのもので小核ができる.

Figure 5 には，典型的な小核形成の顕微鏡写真を示 す。スギ抽出物の処理後に観測した小核形成頻度を Fig. 6 と 7 に示す。 スギ抽出物の濃度の違いによる 効果の有無も検討するため, $0.05 \%, 0.02 \%$, 及び $0.002 \%$ で行った（SVGp12 細胞では，低い濃度の $0.02 \%$ 及び $0.002 \%$ 用い, MO54 細胞では高濃度 の $0.05 \%$ 及び $0.02 \%$ 用いた). スギ抽出物単独処 理 1 時間並びに DMSO 単独処理 1 時間をした細胞 では小核形成頻度の増加はみられなかった。一方,

SVGp12 細胞では，陽性対照として使用したブレオ マイシン処理 $(10 \mu \mathrm{g} / \mathrm{mL})$ によって, DMSO やス ギ抽出物の存在にかかわらず，それぞれの対照と比 較して, 小核形成頻度が増加し，有意な差がみられ た．MO54 細胞では，ブレオマイシン単独並びに DMSO との併用処理で，それぞれの対照と比較し て, 小核形成頻度が増加し, 有意な差がみられた。 ブレオマイシンとスギ抽出物との併用処理では, 無 処理対照と比較した場合は, 統計的な差異はなく, 小核形成頻度がスギ抽出物により有意に減少した。 ただ，ブレオマイシンとスギ抽出物（0.02\%）を DMSO 単独処理と比較した場合には，有意な減少 ではないが，減少傾向としては認められた。これら の SVGp12 細胞と MO54 細胞の結果から，有意性 の有無はあるが， スギ抽出物の濃度の違いにより, ブレオマイシン誘発小核形成抑制傾向がみられた。

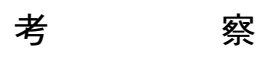

日本人の多くは，建築材料や家具からのスギの香
りが精神を安定させ，健康によいものと感じている. Matsubara \& Kawai25) は，日本のスギ材を使った 内装から放出される揮発性有機化合物による精神生 理学の効果についての評価を試み, 唾液中の $\alpha$ ア ミラーゼ活性とクロモグラニン $\mathrm{A}$ 分泌増加の抑制 を発見した。 それらの抑制は，被験者に匂いを心地 よく感じさせる。.また，Ohira et al. ${ }^{26)}$ は，スギ材 からの揮発性有機化合物の官能検査を 18 人の男子 大学生で行い, 空気乾燥材と従来乾燥材の揮発性化 合物が，高温乾燥材のものと比べて有意に清爽であ ることを報告している。このような背景から，本論 文では，細胞レベルにおけるスギ抽出物の効果の有 無を検索する目的で，ヒト由来の脳細胞 [正常（グ リア細胞由来), 腫瘍 (神経膠腫由来)］を用いて,

ストレスタンパクの 1 種である Hsp70 の発現, 並 びに細胞遺伝毒性で発がん性の指標の 1 つである小 核形成に与える影響を検討した。

熊本県産の約 40 年生スギ材を材料とした，スギ 材精油中に含まれる化合物は Table 1 に示す通りで ある．スギ材の精油中に含まれる化合物に関して過 去に報告されているが，モノテルペン類を始めとし

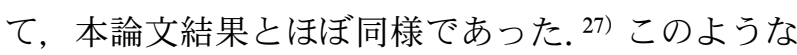
化合物とがんとの関連性については，東南アジアの ショウガのセスキテルペンである Zerumbone や Xylopia frutescens AUBL.の葉精油の化合物が抗腫 瘍効果を有すると示唆する報告がある. ${ }^{28,29)}$ 神経膠 腫について，ラット由来の細胞レベルで，抗腫瘍効

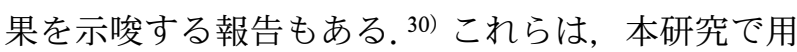
いたスギ材精油中に含まれる主要な化合物とも近い 成分であると考えられる.

熱ショックタンパクに関しては, 古くから最近に 至るまで，その種類や作用機構に関して，主として シャペロン機能として，レビューされている. ${ }^{31-35)}$ さらに, ごく最近のレビューでは, 熱ショックタン パクとがんが極めて深く関連していることを示唆し ている. ${ }^{36,37)}$ 本研究では, ヒト脳由来細胞におい て，温熱処理によるHsp70 の発現をスギ抽出物が 抑制している (Figs. 3 and 4)。熱ショックタンパク の中でも, Hsp70 に注目すると, 種々の細胞種で, Hsp70 の発現促進が，抗がん剂処理，紫外線照射 や活性酸素などによるアポトーシス抑制に関与する という論文が多く報告されている. ${ }^{38-42)}$ その裏返し で，Hsp70の発現が抑制されると，これらの処理 


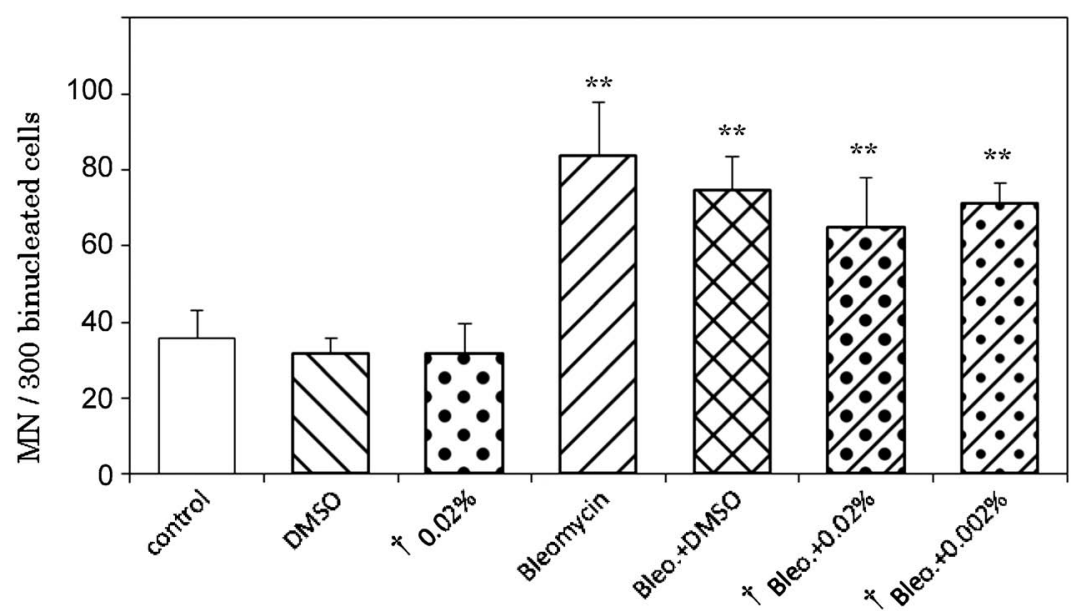

Fig. 6. Frequency of Micronucleus Formation in SVGp12 Cells

After various treatments with bleomycin, DMSO, or extracts from Japanese cedar wood, cells were cultured with cytochalasin B for $24 \mathrm{~h}$. Then, cells were fixed and stained with PI. Three hundred binucleated cells were observed with a microscope and the number of cells with a micronucleus (MN) was measured. Results obtained from at least three independent runs are presented as means \pm S.D. ${ }^{\dagger}$ Treatment with extracts from cedar wood, ${ }^{* *} p<0.01$.

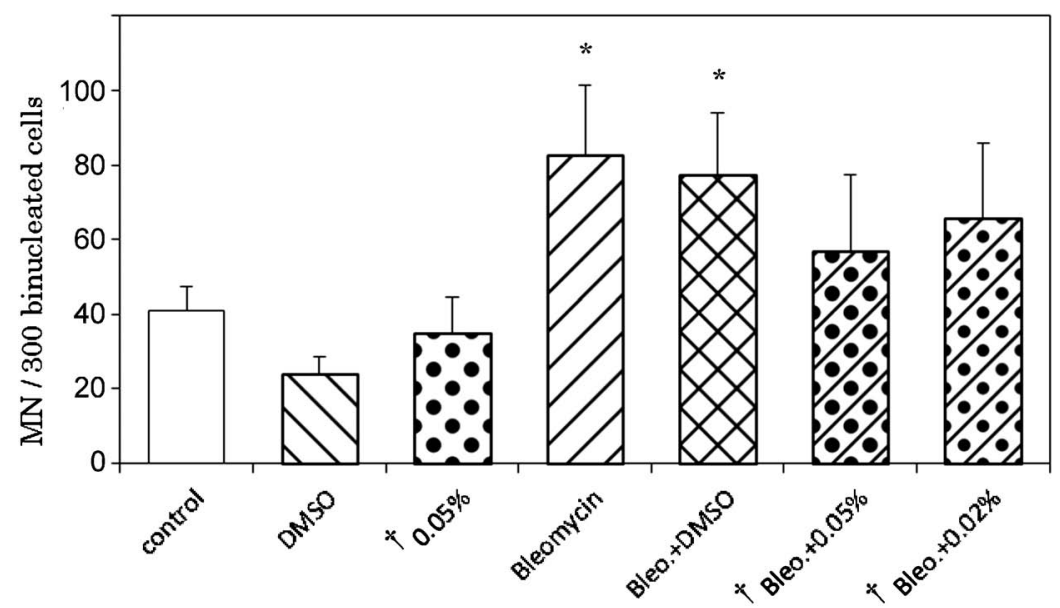

Fig. 7. Frequency of Micronucleus Formation in MO54 Cells

After various treatments with bleomycin, DMSO, or extracts from Japanese cedar wood, cells were cultured with cytochalasin B for $24 \mathrm{~h}$. Then, cells were fixed and stained with PI. Three hundred binucleated cells were observed with a microscope and the number of cells with a micronucleus (MN) was measured. Results obtained from at least three independent runs are presented as means \pm S.D. ${ }^{\dagger}$ Treatment with extracts from cedar wood, ${ }^{*} p<0.05$.

によりアポトーシスが誘発されることを示す論文も 多く発表されている.43-48) このように, Hsp70の発 現誘導や抑制により，多くの細胞種において，抗が ん剤などによる細胞のアポトーシスがコントロール されている. したがって, スギ抽出物の存在で, 温 熱によるHsp70 の発現誘導が抑制されることは, 細胞の持つアポトーシスへと進む過程における Hsp70 の阻害効果が緩和されているものと考えら れる.

熱ショックタンパクの発現とがん細胞の増殖との 関連性についてもいくつか報告がある. Bag3 タン パクはHsp70 タンパクとの結合により，それらの
タンパクは活性化する. PJ-98 という薬剤と Bag3 を結合させることによって，Hsp70 との結合を阻 害することで，Hsp70 の活性が抑えられ，抗がん 作用がみられている. ${ }^{49)}$ また，上述したように，

Hsp70 がアポトーシス抑制に関与していることか ら，Hsp70 に結合する ATPase の活性を阻害する低 分子により, がん細胞が死滅することも報告されて いる. ${ }^{50)}$ さらに，がんの温熱療法に（ハイパーサー ミア）おいて，Hsp70 阻害剤の pifithrin- $\mu$ (PFT- $\mu)$ との併用により, 温熱療法による治療効果が増大 し, 前立腺がんの増殖を抑え, がん細胞を死滅させ

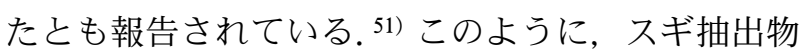


の持つ Hsp70 の発現抑制効果は, がん細胞の増殖 阻害に結び付く可能性も考えられる.

ここまでがんと Hsp70の関与について述べてき たが，その他の熱ショックタンパク質でも，がんと 深く関連していることを示唆する報告がある. Hsp27 について，特にリン酸化 Hsp27 の増加とが んの増殖促進，アポトーシスの抑制など，Hsp70 と同じような結果が認められている. ${ }^{52-54)}$ ただ,

Hsp27 については，この逆のがん抑制に関する報 告55,56) もある. 最近，Hsp90 についてもがんとの 関連性が報告されている. ${ }^{57)}$ スギ抽出物の持つがん との関連性で，Hsp70 の発現抑制効果について考 察してきたが, 他の熱ショックタンパク発現への影 響について検討することは今後の課題の 1 つである.

一方，本論文では，スギ抽出物の発がん性への効 果の有無として, 細胞の小核形成頻度に与える影響 も検討した。細胞レベルでのこうした研究では,

DNA 損傷や染色体異常などを指標とする遺伝毒性 の評価で行う。染色体異常で，染色体の一部がフラ グメントとして，細胞分裂期に核から離れる現象で ある. ${ }^{23,24)}$ 小核形成と発がんとの強い関連性を示唆 する報告58-60) もあり，筆者らは，細胞レベルでの， スギ抽出物の発がん性への効果の有無を検討する指 標として選んだ。国際的に発がん性評価を行ってい る世界保健機関（WHO）の付属組織，国際がん研 究機関 (International Agency for Research on Cancer; IARC) においても，その報告書（モノグラフ） で，細胞レベルの発がん性評価に小核形成頻度を取 り上げている. ${ }^{61)}$ スギ抽出物の効果としては, Hsp70 の発現誘導抑制ほど顕著ではないが，異な る濃度で小核形成頻度の減少傾向が認められた。

(Figs. 6 and 7) この結果は，スギ抽出物が発がんを 抑制する方向に働いている可能性を示唆しているも のであり,さらに詳細な実験を進めなければならな い.

本論文では，スギ抽出物が細胞レベルにおいて， 温熱処理によるHsp70 の発現を抑制する効果を有 することが示された．スギ抽出物の分析結果から， Hsp70 発現抑制効果がどの化合物の寄与によるも のか, そのメカニズムも含めて, 解明する必要があ る. Hsp70の発現とがんとの関連性については数 多くの報告があり，その中でも，細胞のアポトーシ ス誘導への作用がほぼ明らかとなっている。スギ抽
出物とアポトーシスとの関連性についても，そのメ カニズムも含めて，今後検討を進めてゆかねばなら ない．また，Hsp70の発現抑制とがん治療に関す る報告があり，本論文の結果から，スギ抽出物がそ の役割の一端を担える可能性が考えられる。した がって，将来に向けて，スギ抽出物の，特にがん治 療での医療応用という視点からの研究も考えられ る。一方，スギ抽出物の発がん性への関与として は，高濃度 $(0.05 \%)$ では，有意にブレオマイシン 誘発小核形成頻度が減少し，0.02\%濃度でもその減 少傾向は観察された。 スギ抽出物の発がん抑制効果 という観点から論ずるにはまだ遠いが，非常に興味 深い結果と考えている，本論文では，細胞実験の限 界もあり，短時間（1 時間）処理の実験を行ってき た。スギ抽出物のがん治療を含めた医療応用という 方向では，毒性がなければ高濃度のスギ抽出物でも 問題ないが，本来，われわれの生活環境において は，極めて低濃度で，長時間，スギ抽出物に触れる ことが多い．使用するスギ抽出物の濃度や処理時間 も幅広く取って，上述した，今後の研究を推進しな ければならない。

謝辞本研究の推進にあたり, 藤田佐枝子氏 [(有) ホームアイ］には実験材料の調達に関して多 大なご尽力を頂いた．また，本論文執筆に当たり， 摂南大学薬学科・山岸伸行教授から, 熱ショック夕 ンパクとがんに関して助言を得た。さらに，本研究 の一部は京都大学生存圈研究所の新領域研究開拓プ ロジェクトの支援を受けた。 ここに深く感謝する.

利益相反＼cjkstart開示すべき利益相反はない.

\section{REFERENCES}

1) Cheng S.-S., Lin H.-Y., Chang S.-T., J. Agric. Food Chem., 53, 614-619 (2005).

2) Shih Y.-H., Chang K.-W., Hsia S.-M., Yu C.C., Fuh L.-J., Chi T.-Y., Shieh T.-M., Microbiol. Res., 168, 254-262 (2013).

3) Morikawa T., Ashitani T., Kofujita H., Takahashi K., Eur. J. Wood Wood Prod., 72, 651657 (2014).

4) Lee S.-H., Do H.-S., Min K.-J., Plos One, 10, e0143450 (2015).

5) Samali A., Orrenius S., Cell Stress Chaper- 
ones, 3, 228-236 (1998).

6) Hendrick J. P., Hartl F.-U., Annu. Rev. Biochem., 62, 349-384 (1993).

7) Bukau B., Horwich A. L., Cell, 92, 351-366 (1998).

8) Hartl F.-U., Hayer-Hartl M., Science, 295, 1852-1858 (2002).

9) Saito Y., Yamagishi N., Hatayama I., J. Nara Med. Assoc., 61, 73-80 (2010).

10) Cioca D. R., Clark G. M., Tandon A. K., Fuqua S. A,. Welch W. J., McGuire W. L., J. Natl., Cancer Inst., 85, 570-674 (1993).

11) Volm M., Koomägi R., Mattern J., Efferth T., Clin. Exp. Metastasis, 19, 385-390 (2002).

12) Gabai V. L., Meriin A. B,. Mosser D. D., Caron A. W., Rits S., Shifrin V. L., Sherman M. Y., J. Biol. Chem., 272, 18033-18037 (1997).

13) Meriin A. B., Yaglom J. A., Gabai V. L., Mosser D. D., Zon L., Sherman M. Y., Mol. Cell. Biol., 19, 2547-2555 (1999).

14) Watanabe K., Yabe T., Itohara K., Toriizuka K., Cyon J.-C., J. Trad. Med., 14, 157-162 (1997).

15) Koika N., Hosokawa N., Komano T., Hirayoshi K., Nagata K., Ueda K., FEBS Lett., 301, 307-309 (1992).

16) Picone P., Nuzzo D., Caruana L., Messina E., Scafidi V., Di Carlo M., Free Radic. Res., 48, 1397-1408 (2014).

17) Kiaei M., Kipiani K., Petri S., Chen J., Calingasan N. Y., Beal M. F., Neurodegener. Dis., 2, 246-254 (2005).

18) Rozza A. L., Moraes T. M., Kushima H., Tanimoto A., Marques M. O. M., Bauab T. M., Hiruma-Lima C. A., Pellizzon C. H., Chem. Biol. Interact., 189, 82-89 (2011).

19) Sakurai T., Narita E., Shinohara N., Miyakoshi J., J. Radiat. Res., 54, 1005-1009 (2013).

20) Sakurai T., Kiyokowa T., Narita E., Suzuki Y., Taki M., Miyakoshi J., J. Radiat. Res., 52, 185-192 (2011).

21) Miyakoshi J., Yoshida M., Shibuya K., Hiraoka M., J. Radiat. Res., 41, 293-302 (2000).

22) Honda N., Yagi K., Ding G.-R., Miyakoshi J., J. Radiat. Res., 43, 283-292 (2002) .

23) Koyama S., Narita E., Shimizu Y., Suzuki Y., Shiina T., Taki M., Shinohara N., Miyakoshi J., Int. J. Environ. Res. Public Health, 13, pii:
E802 (2016).

24) Countryman P. I., Heddle J. A., Mutat. Res., 41, 321-331 (1976).

25) Matsubara E., Kawai S., Build. Environ., 72, 125-130 (2014).

26) Ohira T., Park B.-J., Kurosumi Y., Miyazaki Y., J. Wood Sci., 55, 144-148 (2009).

27) Cheng S., Lin H.-Y., Chang S.-T., J. Agric. Food Chem., 53, 614-619 (2005).

28) Murakami A., Takahashi D., Kinoshita T., Koshimizu K., Kim H.-W., Yoshihiro A., Nakamura Y., Jiwajinda S., Terao J., Ohigashi H., Carcinigenesis, 23, 795-802 (2002)

29) Ferraz R. P., Cardoso G. M., da Silva T. B., Fontes J. E., Prata A. P., Carvalho A. A., Moraes M. O., Pessoa C., Costa E. V., Bezerra D. P., Food Chem., 141, 196-200 (2013).

30) Uçar E. Ö., Arda N., Aitken A., Genet. Mol. Res., 11, 2801-2813 (2012).

31) Ohtsuka K., Annual Report of Research Institute for Biological Function, 13, 22-40 (2012).

32) Hendrick J. P., Hartl F.-U., Annu. Rev. Biochem., 62, 349-384 (1993).

33) Samali A., Orrenius S., Cell Stress Chaperones, 3, 228-236 (1998).

34) Bukau B., Horwich A. L., Cell, 92, 351-366 (1998).

35) Craig E. A., Marszalek J., Trends Biochem. Sci., 42, 355-368 (2017).

36) Wu J., Liu T., Rios Z., Mei Q., Lin X., Cao S., Trends Pharmacol. Sci., 38, 226-256 (2017).

37) Vahid S., Thaper D., Zoubeidi A., Recent Pat. Anticancer Drug Discov., 12, 35-47 (2017).

38) Jäättelä M., Int. J. Cancer, 60, 689-693 (1995).

39) Mosser D. D., Caron A. W., Bourget L., Denis-Larose C., Massie B., Mol. Cell. Biol., 17, 5317-5327 (1997).

40) Nylandsted J., Brand K., Jäättelä M., Ann. NY Acad. Sci., 926, 122-125 (2000).

41) Beere H. M., Wolf B. B., Cain K., Mosser D. D., Mahboubi A., Kuwana T., Tailor P., Morimoto R. I., Cohen G. M., Green D. R., Nat. Cell Biol., 2, 469-475 (2000). 
42) Saleh A., Srinivasula S. M., Balkir L., Robbins P. D., Alnemri E. S., Nat. Cell Biol., 2, 476-483 (2000).

43) Jäättelä M., Wissing D., Kokholm K., Kallunki T., Egeblad M., EMBO J., 17, 61246134 (1998).

44） Nylandsted J., Rohde M., Brand K., Bastholm L., Elling F., Jäättelä M., Proc. Natl. Acad. Sci. USA, 97, 7871-7876 (2000) .

45) Creagh E. M., Carmody R. J., Cotter T. G., Exp. Cell Res., 257, 58-66 (2000) .

46) Wei Y. Q., Zhao X., Kariya Y., Teshigawara K., Uchida A., Cancer Immunol. Immunother., 40, 73-78 (1995).

47) Kaur J., Kaur J., Ralhan R., Int. J. Cancer, 85, 1-5 (2000).

48) Yoshidomi K., Murakami A., Yakabe K., Sueoka K., Nawata S., Sugino N., J. Obstet. Gynaecol. Res., 40, 1188-1196 (2014) .

49) Li X., Colvin T., Rauch J. N., Acosta-Alvear D., Kampmann M., Dunyak B., Hann B., Aftab B. T., Murnane M., Cho M., Walter P., Weissman J. S., Sherman M. Y., Gestwicki J. E., Mol. Cancer Ther., 14, 642-648 (2015).

50) Ko S. K., Kim J., Na D. C., Park S., Park S.H., Hyun J. Y., Baek K.-H., Kim N. D., Kim N.-K., Park Y. N., Song K., Shin I., Chem. Biol., 22, 391-403 (2015).

51) Sekihara K., Harashima N., Tongu M., Tamaki Y., Uchida N., Inomata T., Harada M., Plos One, 8, e78772 (2013).

52) Katsogiannou M., Andrieu C., Rocchi P., Front. Genet., 5, 346 (2014).

53) Leszczynski D., Joenväärä S., Reivinen J., Kuokka R., Differentiation, 70, 120-129
(2002) .

54) Matsunaga A., Ishii Y., Tsuruta M., Okabayashi K., Hasegawa H., Kitagawa Y., Oncol. Lett., 8, 2496-2500 (2014).

55) Nakashima M., Adachi S., Yasuda I., Yamauchi T., Kawaguchi J., Itani M., Yoshioka T., Matsushima-Nishiwaki R., Hirose Y., Kozawa O., Moriwaki H., Cancer Lett., 313, 218-225 (2011).

56) Matsushima-Nishiwaki R., Takai S., Adachi S., Minamitani C., Yasuda E., Noda T., Kato K., Toyoda H., Kaneoka Y., Yamaguchi A., Kumada T., Kozawa O., J. Biol. Chem., 283, 18852-18860 (2008).

57) Ghadban T., Dibbern J. L., Reeh M., Miro J. T., Tsui T. Y., Wellner U., Izbicki J. R., Güngör C., Vashist Y. K., Apoptosis, 22, 369380 (2017).

58) Crasta K., Ganem N. J., Dagher R., Lantermann A. B., Ivanova E. V., Pan Y., Nezi L, Protopopov A., Chowdhury D., Pellman D., Nature, 482, 53-58 (2012).

59) Terradas M., Martin M., Tusell L., Genescà A., Mutat. Res., 705, 60-67 (2010) .

60) Vral A., Fenech M., Thierens H., Mutagenesis, 26, 11-17 (2011).

61) International Agency for Research on Cancer (IARC), Working Group on the Evaluation of Carcinogenic Risk to Humans, "IARC Monographs on the Evaluation of Carcinogenic Risks to Humans, Vol. 102, Non-ionizing Radiation, Part 2: Radiofrequency (RF) Electromagnetic Fields,"' IARC, Lyon, 2011, pp. 301-329. 